\title{
6. Freelancing globally: Upworkers in China and India, neo-liberalisation and the new international putting-out system of labour (NIPL)
}

\author{
Wing-Fai Leung, Premilla D'Cruz and \\ Ernesto Noronha
}

\section{INTRODUCTION}

Digitalisation has taken place at a global level, exporting business models across continents and increasing the possibility of casual work, while preventing unions and governments from scrutinising employment malpractice (Holtgrewe 2014; Moore 2018). The new digital workplace has profound effects on workers and their professional identities. The global expansion of digital 'platforms', whether entailing online (e.g., Amazon Mechanical Turk/ AMT) or offline (e.g., Uber) work also exports the Western entrepreneurial ideal as a universally valorised symbol of good work and an opportunity for democratic participation in the information society (Cohen 2015). The contemporary online 'gig economy' represents a new means of livelihood, taking forward its earlier manifestation as home-based medical transcription which was offshored to developing countries such as India (Noronha \& D'Cruz 2008). Sitting at the cusp of neo-liberalism ${ }^{1}$ and technology (D'Cruz 2017), online labour markets are seen as critical drivers in the further expansion of the service outsourcing/offshoring sector (Beerepoot \& Lambregts 2015), thereby reconfiguring the international division of labour while extending global value chains (Huws 2013), to form a planetary labour market (Graham \& Anwar 2019).

Crowdsourcing through digital platforms such as Upwork and Freelancer changes the nature of freelancing as the platforms allow the combination of 'crowd' and 'outsourcing' (Howe 2006), bridging a global market with individual workers, making it possible for workers to be hired for projects or tasks on short-term contracts. At the same time, crowdsourcing reflects the 
increasing casualisation of white-collar employment and the informalisation of work in the digital age (D'Cruz \& Noronha 2019; de Stefano 2016a). However, existing studies mostly consider the experiences of workers in the West (Bergvall-Kåreborn \& Howcroft 2014; Cushing 2013; Irani 2015), even though platforms are populated by large numbers of workers from across the world (Graham et al. 2017).

Platforms such as AMT and Upwork connect requesters and freelancers and extract revenue through fees. Freelancers can offer skills, bid for work, receive payment digitally and have flexibility and access to a wide range of potential employers. Firms or individual requesters can access workers at a low cost and avoid the legal costs (contracts, benefits, etc.) associated with conventional subcontracting (Bergvall-Kåreborn \& Howcroft 2014; Ettlinger 2016). Clients have no responsibility towards freelancers beyond the scope of the projects/ jobs (D'Cruz \& Noronha 2016). Moreover, platforms usually exist beyond any form of democratic oversight, whether regulatory, state linked or worker led (Pongratz 2018; Urry 2014), contributing to the deregulation of work, especially in Western neo-liberal economies.

If, on the one hand, digital platforms provide greater opportunity for participation in a virtual sphere, on the other hand, they also increment the options for exploitation of labour for capital accumulation in the service sector, offering increased autonomy to contract workers in exchange for low-paid and precarious work (Milkman \& Ott 2014; Wood et al. 2018). The global workforce comprises workers from different countries competing with each other. In order to retain competitiveness, workers have to accept the demands of capital or production may simply be moved to other geographical locations where workers are more amenable, engendering new forms of labour exploitation (Bieler \& Lee 2017a, p. 182; Fuchs 2013; Standing 1999). Global labour is supposed to manage their life as individual 'entrepreneurs' whereby 'the individual [flexible] subject [...] progressively resembles the homo economicus imagined by neoliberal economists' (Ouellet 2010, p. 180).

We can consider digital platforms as a new form of the international division of labour (NIDL); the NIDL referred to industrial restructuring and the shift of manufacturing work from the developed world to the developing world, especially China and India. The rise of the term in the 1970s (Frobel et al. 1978) implied the zero-sum game between jobs in the West and the developing countries, with academic interest being predominantly about the effects the NIDL had on the Global North, especially on traditional manufacturing industries and the levels of unemployment. The effect in developing countries was characterised by 'proletarianization and impoverishment of ever-growing numbers of people' (Frobel et al. 1978, p. 124). Nash (1983) notes the weak bargaining power of workers from developing countries due to international capital investments. For instance, in the Indian context, Noronha (1996) 
argues that NIDL resulted in the demand for labour flexibility, an increase in non-standard jobs and the weakening of trade unions. Today, the production of information and information technology is part of an NIDL that shapes modes of production, distribution and consumption (Fuchs 2016). We contend that the platform economy continues and updates the practice of the NIDL whereby the workforce in developing countries, including China and India, participate in employer-labour interactions (control and bargaining) through platforms such as Upwork, with its invisible management logic and its individualist, entrepreneurial slant (Caraway 2010; D'Cruz \& Noronha 2019). In addition, we argue that platforms and requesters can enjoy the benefits of the putting-out system such as inadequate employment law coverage and labour arbitrage emanating from global competition between freelancers, limiting worker solidarity and avoiding sunk costs (de Stefano 2016b). In fact, Kenney and Zysman (2016) argue that platform work has more than a passing resemblance to the putting-out economy that was prominent in the pre-Industrial Revolution era when companies would ship materials to people to assemble items such as shoes, clothing or firearms in their homes. In the current manifestation of the putting-out system, the platform, while still claiming to be only an intermediary, has unprecedented control over the compensation for and organisation of work. Platforms such as AMT, Upwork and InnoCentive have created similar global virtual labour exchanges which enable companies to crowdsource the performance of specific tasks that require human judgement; they are a modern form of the putting-out system (Kenney \& Zysman 2016). Therefore, we hold that the platform economy combines the characteristics of the NIDL and the putting-out system which we term and develop as the new international putting-out system of labour (NIPL). We conceptualise NIPL to mean that, unlike the first wave of outsourcing which involved activity between different firms and organisations under NIDL, digital work platforms can put out work from big firms, small businesses and individual clients directly to individual workers and small enterprises who telework from anywhere in the world. This has been induced by neo-liberal policies which have reversed the movement of work from home-based artisanal workshops to factories, as evident in the industrial era, back to individuals in the current globalisation period (Noronha \& D'Cruz 2019). Nonetheless, like the pre-industrial system, the NIPL eliminates or reduces employers' costs of real estate, equipment, supervision, management and labour while also providing product market flexibility and stalling workers' collective action (Finkin 2016; Noronha \& D'Cruz 2008).

This chapter is a comparative study of Upwork freelancers from China and India, two BRICS countries, which represent rising economies but with contrasting political, social and cultural conditions. The GDP per capita of the two countries shows the different standards of living: US $\$ 8770$ for China, US\$2015 for India. ${ }^{2}$ Globally, India is ranked second after the USA among 
freelancer nations, with about 15 million freelancers (Lal 2015) who take up 40 per cent of the freelancer jobs offered around the world (Elena 2017). The Oxford Internet Institute (OII) shows that within online platforms, while writing and translation are the top categories in the USA, in India, software development and technology dominate (55 per cent of market share), followed by creative work and multimedia. According to the OII, China was not in the top 20 countries where online labour workers were located. Developed countries dominate as the origin of online employers while 'the majority of work is carried out in low-income countries' (Graham et al. 2017, p. 142). Across the globe, the Chinese online workers were in the 90-100 percentile (US\$20.1-100) in terms of the median hourly pay requested, while their Indian counterparts were in the 10-25 percentile (US\$5.1-9.9) (Graham et al. 2017, p. 144). The two cases will, therefore, provide a valuable contribution to the debates around digital platform work.

In completing this comparison between Chinese and Indian Upworkers, our main concerns are to examine (a) the extent to which online freelance work in developing economies represents 'decent work', ${ }^{3}$ and (b) how freelancers' participation in the global digital platform economy can be understood through the lenses of neo-liberalism and NIPL. After describing the Upwork platform and the methodology of each country's study, the chapter presents the findings in terms of labour conditions, referencing neo-liberalism, and freelancers' experiences of platform work. The chapter concludes with an analysis discussing online freelance work in terms of decent work and the NIPL.

\section{FREELANCING ON UPWORK}

Upwork is a skilled digital workplace (Kittur et al. 2013) formed in May 2015 as the result of a merger of Elance and oDesk. Upwork has 12 million registered freelancers and 5 million registered clients, with 3 billion jobs posted annually and more than US\$1 billion worth of work done annually (Graham \& Anwar 2019). The platform allows members of the labour force to compete directly as independent freelancers with their international counterparts, offering their services to requesters around the world (Green et al. 2013; Huws 2013). Digital platforms such as Upwork carry no liabilities for clients and freelancers (Caraway 2010) but retain a percentage of the payment between these two parties as their fee (Aloisi 2015). Upwork hosts remunerative jobs of varying temporality and complexity (Green et al. 2013), with most clients coming from developed countries and most freelancers coming from developing economies and often being poorly rewarded (Graham et al. 2017).

The platform provides employment opportunities but acquiring requisite skills and training are left to individual freelancers. Workers are also responsible for the facilities and resources they need to carry out the work, including 
workspace, power, computer/mobile devices, software requirements and so on (Caraway 2010). Upworkers set up their own profile, bid for jobs, gain experience and endeavour to receive good reviews and build a reputation. Contracts and management of the requester-crowdsourced worker relationship are conducted through a series of online mechanisms such as reviews, escrow and arbitration. Work is risky both in terms of whether Upworkers can secure projects and whether their rights are respected. Freelancers are not covered by unions or government regulation. There is no legal protection since crowdsourcing is 'borderless' (Bergvall-Kåreborn \& Howcroft 2014; Caraway 2010).

In spite of these shortcomings, Upwork has in place some mechanisms which protect the interests of freelancers (D’Cruz \& Noronha 2019). First, the platform conducts identity checks of all those signing up, which lowers the risk of freelancers being misled. Second, the platform specifies a minimum remuneration for both hourly and fixed price projects. Third, the platform monitors freelancer and client behaviour to ensure that rules pertaining to gaining/posting jobs and interacting with freelancers and clients during the course of work are followed. Fourth, redress mechanisms available on the platform address freelancer and client grievances, covering task-related, payment-related and interpersonal issues which occur on the site (D'Cruz \& Noronha 2016).

\section{METHODOLOGY}

Leung conducted research in 2016 on freelancers in Greater China (mainly China with a minority of participants based in Asia) who use the online platforms, Elance-oDesk and later Upwork. She carried out the study through a detailed questionnaire: a 40-question survey of 20 Upworkers who were Chinese-English/English-Chinese translators. She 'hired' the freelancers on Upwork to complete the survey as their task and each was paid for the work. In some of the cases, the researcher asked follow-up questions or clarification via email and the messaging service within Upwork. The job role of a translator was chosen as this group was more likely to interact with global clients. Leung also noted participants' profiles, which were publicly available, and detailed their work history, skills, jobs and ratings, where they were located and their qualifications. A grounded approach was used to organise and analyse the data.

D'Cruz and Noronha adopted a qualitative strategy to study Indian freelancers' subjective experiences of work on the online platform Elance-oDesk and later Upwork. In 2015, freelancers were contacted via a research call on various social networking sites as well as Internet searches. Twenty-four Elance-oDesk freelancers (15 full-timers and 9 part-timers) from across India, whose jobs on the platform included data entry, research assistance, content 
writing, marketing and public relations, business analytics and numerous information technology applications, completed the interview process. Participants' locations necessitated data collection via telephonic interviews. Unstructured conversational interviews were conducted and subjected to thematic analysis.

The comparative research does not match data sets, but rather analyses the themes emerging from the respective studies in China and India, which allows the researchers to focus on key issues: the experiences and quality of online work juxtaposed vis-à-vis decent work, and the role the platform economy serves in the global flows of digital labour, adopting the frames of neo-liberalism and NIPL.

\section{LABOUR CONDITIONS IN CHINA AND INDIA AND NEO-LIBERALISATION}

Since the Open Door policy of the late 1970s, there has been a gradual break-up of state-owned enterprises in China. The sharp decline of employment in the state sector, particularly from the late 1990s, was achieved mainly through downsizing, plant closures and privatisation of state-owned enterprises as part of state-driven reform. Consequently, the urban workforce employed in the state sector had been reduced from more than 78 per cent to around 19 per cent by 2012 (Cooke 2016). Since then, China has emerged as the assembly platform of global capital. In line with this assembly role, China's contribution is often limited to providing cheap labour to maintain international competitiveness (Hart-Landsberg 2015). Thus, despite moving rapidly into export of manufactured goods as part of the NIDL, China's production is mainly based on cheap labour, low value-added activities, dominated by foreign TNCs and highly dependent on access to markets elsewhere (Bieler \& Lee 2017b). The shift from the protection of secure formal employment within state-owned enterprises to the rise of private businesses subject to fluctuating market demands accompanied the rise of the number of workers who do not have a formal contract or who perform casual work in an informal economy (Liang et al. 2016). According to the ILO (2018, p. 88), the percentage of workers in informal employment was 54.5 per cent. Most of the rise in informal employment has taken the form of casual workers who receive lower levels of remuneration and report lower subjective well-being than formal employees (Liang et al. 2016).

Unemployment rates in China have remained low at 4.4 per cent in $2019 .{ }^{4}$ However, urban youth (16-24 years) unemployment is estimated to be 9.04 per cent (Schucher 2017, p. 79). While mass manufacturing has prompted the rapid development of the economy, high-skilled jobs are in fact in short supply, reflected in the postgraduate unemployment rates in urban China (10.4 per cent) and rural China (45.3 per cent) (ibid. p. 84). This is evidence that though 
education standards have risen over time, graduate jobs have recently become scarcer and therefore more competitive. In 2017, 8 million young people graduated from university, ten times more than ten years ago. ${ }^{5}$ Desirable stable and highly skilled professional jobs are hard to come by. Nearly 12 per cent of graduates opted for flexible employment, such as freelancing, setting up one's own business or informal work (ibid. p. 85). For those who have access, freelancers on international work platforms can partake of job opportunities previously unavailable to the local labour market. However, the online platform economy, because of the regulatory challenges it faces, thrives on turning informal workers into platform labourers in China by appropriating labour and increasing vulnerability (Chen 2018).

Though India is counted among the emerging economies of the world, employment conditions remain dismal (India Labour and Employment Report/ ILER 2014). The poor availability of jobs, nature of the employment contract and problems associated with working conditions (Rustagi 2015) are more pronounced among particular social categories and in smaller cities and towns and rural areas, precipitating under-employment and unemployment (ILER 2014) and violating workers' rights (Kapoor 2014). Non-standard employment, with limited or no regulation, social protection and social dialogue (Williams 2017), accounts for over 92 per cent of the Indian workforce (ILER 2014). The latest census data of 2011 highlights the especially high unemployment numbers for youth between 15 and 29 years. Many unemployed are educated and looking for jobs commensurate with their abilities (ILER 2014). Good quality employment is 'rare', with access to it 'extremely unequal' (ILER 2014, p. 25). India's espousal of neo-liberalism in 1991, accompanied by the deregulation of employment and attempts at labour law reform, has led to a conscious policy to shift labour from formal to informal contracts (Noronha \& Beale 2011; Noronha \& D'Cruz 2018), accentuating the aforementioned scenario. In these circumstances, the IT industry has become an icon of development (Noronha \& D'Cruz 2016). This is because IT employees benefit through higher salaries, better working conditions and mobility in terms of status in society. However, as part of the NIDL, they have to be satisfied with work which is at the lower end of the value chain (Noronha \& D'Cruz 2016; Noronha et al. 2018). Similarly, crowdsourced employment, despite falling within the informal sector (de Stefano 2016a) with its entrepreneurial slant (Holtgrewe 2014) and its emphasis on merit, is an attractive alternative (D'Cruz \& Noronha 2016).

The labour conditions in China and India, therefore, encourage the informal economy and freelancing, especially among younger, educated, Internet-savvy job seekers who are utilising the platforms to gain work that is not limited to the national job market. The major difference is that the proficiency level of English in India makes its educated population a more competitive workforce in the online marketplace. Undoubtedly, because of the necessity of computing 
equipment and skills and Internet access, usually coupled with proficiency in English (Pongratz 2018), it should not be surprising that online gig work is largely limited to particular classes and locations in the Indian subcontinent. Given the nature of work (Chinese-English/English-Chinese translation) of our Chinese participants, they also have to have a good degree in English in order to compete for work. Out of the 20 Chinese participants, 15 have a bachelor's degree and three are master's graduates; 9 out of the 24 Indian interviewees have a bachelor's degree, 13 are master's graduates and two are students. Even so, the expectation of a high level of English on a platform like Upwork generally puts many Chinese freelancers at a disadvantage vis-à-vis other nationalities, such as Indian workers, who have native or near-native proficiency in the language.

The Chinese Upworkers were attracted to the work because of its flexibility and the self-organisation of time and workload (nine), the opportunity for extra income (11), gaining customers globally (five), and learning new skills and working on more diverse projects (six). One of the Chinese workers stated, 'These platforms are like a door to the world for me, which enriches my professional life and always gives me new and creative ideas'. For the 15 Indian participants who worked full-time on the platform, the reasons for their choice were childcare (two), spouse's job/marriage which made location-specific jobs in the local labour market difficult (four), better earning opportunities and career growth (four) and living in small Indian cities and towns with poor labour market conditions which made crowdsourced employment a far more attractive option (five).

In both the Indian and Chinese studies, therefore, online work is a means to improve one's standard of living that can provide opportunities independent of the national labour condition, allowing access to international clients and skills development opportunities. The fact that the informal sector predominates in both countries and hence is not perceived as unusual or especially threatening (ILER 2014) accounts for Chinese and Indian participants' positive views of online platforms such as Upwork. Crowdsourced employment, with its entrepreneurial slant that encourages self-promotion and self-protection, is an attractive alternative for both Indian and Chinese freelancers. Entrepreneurialism has acquired romantic connotations of initiative, energy, boldness, independence, self-reliance and risk-taking (Keat 1991) and is seen as a remedy for broader societal problems, especially among the technical and educated elite in developed and developing Asian countries (see Leung 2018; Leung \& Cossu 2019). Entrepreneurialism emphasises self-sufficiency and personal responsibility for success, being linked to the rise of neo-liberalism and aligned with the retreating welfare state, unfettered markets and lean corporations (Cohen 2015). Having to be entrepreneurial, while entailing self-control, self-commercialisation and self-rationalisation (Pongratz \& Voss 2003), despite its accompa- 
nying uncertainty, variable income and limited statutory entitlements (Vosko 2009), was not seen negatively. Instead, both Indian and Chinese participants considered such commodification and marketisation of themselves to be the basis of their success, a neo-liberal turn that suggests they are co-opted into the American ideological apparatus (Leung \& Cossu 2019).

\section{AGENCY, FLEXIBILITY AND SKILLS DEVELOPMENT}

A striking feature of online platform labour among the Indian and Chinese workforce is the involvement of the middle class and of educated graduates which brings this group, conventionally associated with standard employment, into the unorganised labour market (D'Cruz 2017). Since the economic reforms, Chinese workers are no longer guaranteed jobs for life in state-run work units, and the access to an international market through digital platforms has given the highly qualified Upworkers an individualised outlet. Similarly, India, being at the top of the league in matters of informal employment (Williams 2017), witnesses in its workforce greater individualism and competition for scarce opportunities and resources (Sinha, 2015). The platform economy provides an important means of livelihood, with its entrepreneurialism and merit bases perceived as proxies for agency and mastery (D'Cruz \& Noronha 2016).

Seventeen of the Chinese participants earned less than 60 per cent of their household income from online jobs and only four of them worked over 30 hours per week online. The three participants who earned over 60 per cent of their household income from the platforms reported an annual income of over US $\$ 10,000.00$. The highest annual income (US\$20,000.00-29,000.00) represented 80-100 per cent of a participant's household income. Seven earned less than US\$2500.00, and eight earned between US\$2,500.00 and US\$9,999.00. Thirteen Chinese participants worked part time, combining online work with other jobs; five of them were already freelance translators when joining Upwork. Due to the risks involved in online platform work, the majority of the Chinese participants were part-time and most did not rely on it as their sole source of income. Fifteen Indian participants were full-timers who had online freelance work as their only employment and source of income. Nine were part-timers (two of whom received more than half of their average monthly income from the platform and two were students). Compared to the Chinese Upworkers, the Indian freelancers appeared to rely on the digital platform more in terms of hours of work and income.

The majority of the Chinese participants were single workers (13), relatively free of childcare and the need to support other dependents. Among the five married participants, for example, only two had children, and in each case, 
a single child. Given the One Child Policy, this was unsurprising. ${ }^{6}$ Among the Indian interviewees were women with children (two) as well as women whose husbands' jobs involved periodic relocations to other cities or who had family responsibilities (four). They chose platform work as a means of managing both work and family roles as they did not wish to forgo their links with the world of work. In that sense, Indian participants tended to be influenced by childcare and/or family responsibilities as a reason to use online work platforms. Care responsibilities are not the only reason for choosing online employment, though; 19 out of 20 Chinese participants agreed that online work fits in with their other responsibilities and tasks. Being able to combine personal and family demands, enjoying a satisfactory work trajectory and finding a suitable means of livelihood despite locational constraints were described as positive aspects of working on the platform by the Indian interviewees and as the reasons they opted for full-time crowdsourced employment. In addition, all Indian full-timers appreciated operating from home and avoiding difficult commutes as well as escaping from the micropolitics, supervisory controls and interpersonal issues that accompanied organisational life.

The Chinese sample gave an average of 6.5 out of 10 for being able to utilise their skills in the online jobs, and an average of 7.4 out of 10 for satisfaction with their online work. Correspondingly, they felt only 5.9 out of 10 for satisfaction with their current standard of living. However, many factors, aside from the use of online platforms, might have an impact on this. Being able to organise one's own work life is a sign of emerging individualism - an important aspect of contemporary life in China, and our participants showed a relative high degree of satisfaction with this dimension of work on the crowdsourcing platforms.

The opportunity to utilise one's skills and further one's abilities was considered advantageous by all Indian participants. However, developing new skills was undertaken by participants at their own initiative and cost. All participants appreciated their exposure to foreign clients and freelancers. They could interact with people across the globe, learning about the latter's work and culture. The work ethic of the West in terms of punctuality, precision and quality was praised. Chinese Upworkers reported similar satisfaction with being able to access international clients and with using their translation skills. This is broadly in line with what Graham and his colleagues call 'skill and capability development' (2017, pp. 151-152), though their argument that workers are kept at arm's length by platforms' invisible management, which then limits skill upgrading, contrasts with how the Indian and Chinese freelancers felt about their skill development. 
Crowdwork platforms like Upwork have facilitated the digital outsourcing of work, mostly to countries where labour costs are lower. However, the experiences of the global Upworkers are rather different from the low-waged manufacturing working class that the original NIDL refers to. The workers we studied demonstrated a good level of satisfaction with the platform except for the high fees. Moreover, they observed that the structure of the platform offered some protection against cheating customers, though they reported some negative experiences. The new digital workers enter into their own time arrangement in terms of scheduling, but they are also often inadequately paid for their labour. For instance, 12 of the Chinese participants spent one or two hours a day performing non-paid functions including maintaining their profiles, checking messages, providing good service to gain positive feedback and bidding for work. These tasks were necessary to maintain a good online freelance profile but involved unpaid work. The majority of workers also worked outside of nine-to-five office hours and weekends, a necessity when interacting with international clients due to the time difference that put those located in China behind North America and in front of Europe. Of the Chinese workers, three charged under US $\$ 10.00$ /hour, with one charging only US $\$ 3.00 /$ hour (the lowest). Seven requested an hourly fee between US\$10.00 and US\$20.00. Five charged US $\$ 25.00 /$ hour or US $\$ 30.00 /$ hour. Those who requested over US $\$ 10.00 /$ hour tended to be more qualified and had had more success on the platform. Overall, 18 out of 20 freelancers in the Chinese sample improved their income through the online platforms. The Indian freelancers' rates varied from US $\$ 4.00$ to US $\$ 20.00$ per hour for part-timers and US $\$ 3.50$ to US $\$ 50.00$ per hour for full-timers, with the nature of task on offer, level of skill, duration of work experience, length of platform membership and specificities of platform profile impacting the rate being quoted. Indian IT freelancers sometimes asked for rates between US $\$ 35.00$ and US $\$ 85.00$ per hour for projects and these expectations were met with success. Indian full-timers considered their remuneration from the platform to be better than what the local job market could provide, while Indian part-timers were pleased with the additional income which supplemented the stable returns from their regular jobs.

Nonetheless, workers' pay is usually subject to pre-existing conditions within a global digital economy. Cost-savings for Western companies is a key feature of NIPL, and the platform economy reflects this; workers also have to negotiate fees individually, without recourse to collective bargaining. Average fees per hour vary but usually correspond with the work experience and the number of projects a freelancer has already undertaken. In order to compete with other freelancers, a platform like Upwork can downgrade the rate of pay, 
causing a 'race to the bottom' (Graham et al. 2017; Kneese et al. 2014). There are expectations that workers based in developing economies such as China and India will inevitably accept fees lower than their counterparts in Western countries for the same work, which was confirmed by a Chinese participant who said: 'People may think labour in China should be cheaper than in other regions, forgetting that this is the fastest developing market, with many expats and Chinese [who] have international experience and skills'. Echoing this, an Indian freelancer said:

No doubt, we are paid less than the freelancers from US, UK, Australia, because we are from India. Even though we are skilled and we do good work, we get less. But because of the conversion rate, the money is good. I would get much less locally for the same work.

Similar to their Chinese counterparts, Indian workers spent time acquiring contracts, which involved checking job posts and preparing bids that showcased one's skills, experience, performance and appropriateness for the task. To this end, building a profile, maintaining a positive image, marketing oneself in general and for a job in particular, and being entrepreneurial were important facilitators. Since bids are generally posted during the Indian night (as they mostly originate in the West) and receive quick responses, participants who wish to have a steady supply of work and income have to extend their workdays by staying up to check posts and put together appropriate responses to them. The race to get work resulted in freelancers lowering rates based on the premise that clients' cost-savings agenda would favour less expensive bids in instances of comparable competences. Nonetheless, freelancers would maintain a particular minimum rate for themselves. That the platform also specifies minimum rates is seen as helpful to stall a complete downslide to the absolute bottom.

The Indian and Chinese Upworkers' experiences on the platform reflect the inequality within the NIPL. Thirteen Indians reported being cheated by clients who disappeared after project completion without making payments. Moving off the platform after initial discussions without a contract so as to save the platform fee for themselves and the client, initiating work in the pre-contract stage prior to clients funding the escrow account and opting for payments at the time of task completion in long-term fixed projects left freelancers vulnerable. Not only could clients disappear without paying them but redress via the platform would be limited to situations falling within the purview of stated conditions.

Similarly, twelve Chinese freelancers reported that they had encountered situations where they were not paid or were paid unfairly. Eight freelancers were not paid after completing the work. They reported experiences of clients 
using the timed project work mode rather than the escrow/fixed price structure, making it easier for clients to default after several milestones. Clients could also close the accounts before freelancers completed the work. Three participants reported that they had experienced clients who misrepresented the work involved, which usually meant that freelancers carried out additional work beyond what they were paid for. In these ways, the experiences of both Chinese and Indian workers were analogous. Being deprived of payments, clients' incorrect information about the work, having a greater workload than expected and not being paid overtime were common experiences for Chinese and Indian Upworkers. The platform provides a level of mitigation in the interaction between clients and workers, but workers have to remain vigilant.

The majority of Chinese participants (15) told us that they had not experienced discrimination, but only because it was difficult to know if it had occurred. Being discriminated against on such a platform usually resulted in the freelancers not getting jobs. Only four participants reported discrimination based on nationality, race and gender. The opportunities that were open to workers were constrained by their locations and by assumptions about global workers. For example, it was possible for employers to specify 'native English speakers' which often excluded workers by virtue of their nationality, locations or 'non-English' names. A Chinese participant from Singapore, one of the wealthiest and most developed Asian nations, considered herself a native English speaker as she was fully bilingual, and yet with an obvious Asian name she perceived that she was disadvantaged when the job listings specified 'native speakers'.

In the Indian study, racial discrimination from both clients and fellow freelancers was reported (for a detailed discussion on abuse on online platforms, see D’Cruz \& Noronha 2018a, 2018b; Noronha \& D’Cruz 2018). Similar to the Chinese case, such biases were usually covert and veiled, with obvious instances inviting reprimands from platform administrators. Clients' negative behaviour arose from doubts over freelancers' competence, sometimes with a view to reducing the latter's payments. Western freelancers' negative acts stemmed from competition linked to both skill and remuneration. Apart from seeing Indians as capable and hence threatening, other freelancers considered the lower rates solicited by the developing world as undercutting them and spoiling their earning opportunities.

Such discrimination and attitudes towards Chinese and Indian freelancers are another manifestation of neo-colonialism (Holtgrewe 2014), evidencing the hegemony of the Global North and adding aversive racism to the existing vulnerabilities of informal sector workers in developing countries. The dynamics of the platform economy indicate processes completely antithetical to the earlier claims of the democratisation of society through cyberspace (Ettlinger 2016). The organisation of crowdsourced work is orchestrated from 
the developed world, and though the crowd is global, supposedly leading to the dissolution of boundaries between the Global North and Global South and to the remunerative flattening of the global workforce (Ettlinger 2016), racial biases in selection, wages and interpersonal interactions persist (D'Cruz \& Noronha 2016, 2018a).

\section{CONCLUDING DISCUSSION}

\section{Outsourced Digital Labour as Decent Work}

The platform economy has facilitated the absorption of global freelance workers into the world capitalist system and exports precarity associated with the virtual work business model. Despite the potential of exploitation that exists, Chinese and Indian Upworkers report largely positive experiences of using such platforms. Unfortunately, workers' rights and collective bargaining are not well developed in either country and, therefore, with online employment, Upworkers are as vulnerable as their offline counterparts. In China, the increase in crowdsourced work reflects the gradual adaptation of elements of a capitalist economy since the late 1980s, as a new generation of workers in China has grown up embracing the neo-liberal entrepreneurship ideal (Ong 2006, p. 173). The data discussed herein reveal that freelance workers are mostly young and highly educated and use the online platform to improve their income and work flexibility, enabled by their English language skills. They see freelance work on platforms such as Upwork as opportunities to garner skills and, more importantly, exercise control over their careers. Most of the Chinese participants are single, childless and unmarried. The underlying entrepreneurial ethos and individualism are new to China but represent ways of thinking which have been enthusiastically embraced, especially by younger graduates. While a similar trend can be seen in India, there are other pertinent issues as well. Indian workers who seek opportunities through the global crowdsourced platforms do so in response to poor labour markets and unfavourable working conditions nationally. Indeed, many of them are highly skilled and educated and belong to the middle class, and hence find the online platform a useful means to gaining challenging and satisfying work. Platform work privileges merit and competence, utilises and hones freelancers' skills, exposes workers to the global job market and allows flexible working hours, especially for those who need to combine work with household tasks, in particular childcare responsibilities. Despite the costs, risks and vulnerabilities, the platform strikes a chord with Indian freelancers on two important counts: (1) it represents a move away from the feudalistic ethos that pervades most Indian workplaces making them exploitative and sycophantic (D'Cruz \& Noronha 2012); and (2) it coheres with the growing predominant notions of 
self-realisation and entrepreneurialism, especially among Indian youth, that are evident in the subcontinent thanks to neo-liberal and global influences (D’Cruz \& Noronha 2016).

Though the Indian and Chinese freelancers' subjective experiences of online outsourced work encompassed feelings of well-being, a critical lens highlights several dimensions of disempowerment. This type of work embodies deficits across all four pillars of decent work, including the provision of full and productive employment, rights at work ensuring human dignity, social protection and social dialogue (ILO 1999). Looking at the criteria which include labour market security, employment security, job security, work security, skill reproduction security, income security and representation security (Kantor et al. 2006), freelancers have to put in concerted efforts to ensure labour market security (especially by bidding but undergirded by reputation), employment security (in spite of constraints, abuse and discrimination, etc., optimum performance and behaviour are required to maintain reputation, and platform and project continuity) and income security including long-term safety nets. Skill reproduction security including arranging for infrastructure is fully the freelancers' responsibility as is work security except for the platform's verification checks, behavioural guidelines and grievance redress. Many of the issues platform workers face are similar to those encountered by other precarious workers, making 'parallel and watertight dimension of the labour market with structurally separated feature and needs' (de Stefano 2016a, p. 2) superfluous.

Moreover, workplace mistreatment has been associated with precarious work, in particular poor labour market conditions, inter-worker competition, job insecurity, limited or no social protection and social dialogue, and partial or no regulation (Djurkovic 2018; Noronha \& D'Cruz 2018). Contingent on their job contract and the availability of regulation, social protection and social dialogue, informal workers face varying degrees of liability (Kalleberg 2012; Standing 2011), which has implications for how they tackle situations of abuse and discrimination since mechanisms of redress within and outside workplaces can vary or be (un)available, depending on their particular employment situation (Noronha \& D'Cruz 2018). Indian and Chinese participants share country-linked and capital-linked views of the importance of free market dynamics, glossing over how these harm their interests (D'Cruz \& Noronha 2018b). In so doing, they are hemmed in by their cognition, and reinforce and perpetuate the context surrounding platform labour, furthering the hegemony of the platform and the sway of neo-liberal and cultural ideologies. Emancipatory discourse and social justice are subverted as macro-level thought processes colour individual sensemaking processes (Burbank \& Martins 2010; D’Cruz \& Noronha 2018b). 


\section{The New International Putting-Out System of Labour (NIPL)}

The advantage of the putting-out system is that it enables the outsourcing of work so that employers' costs of real estate, equipment and supervision can be eliminated or reduced and collective action and legal regulation can be avoided, while increasing labour market flexibility emanating from the fluctuation in demand. Employers need not invest in a workplace for the work to be done, or provide the tools (Finkin 2016). In the case of Upwork, workers are also responsible for the workspace, power, computer/mobile devices and software requirements.

Nonetheless, we have developed a context-specific understanding of crowdwork in national conditions. By considering how Chinese and Indian freelancers make use of online opportunities to access international markets for their occupations and professions, we suggest that they are also acculturated to the assumed ethos in the platform economy - neo-liberalism, entrepreneurialism and individual responsibility towards one's career - and they inadvertently reduce the need for supervision. Chinese and Indian Upworkers in the digital economy must accept these notions - many of which are previously unfamiliar codes of work culture - that underpin the platform economy in order to participate in the global flows of virtual work. In the Asian context - shared by Indian and Chinese cultures - individualism is a relatively new ethic. Indian and Chinese workers have been incorporated into work processes that involve self-management, often without adequate compensation and safeguards of labour conditions. The relatively young and educated in both countries have been subsumed by the global discourse surrounding neo-liberalism, and they voluntarily enter into individually negotiated work arrangements with global clients. Besides this, employers can track their experience with workers electronically, thus overcoming the loss of supervisory capacity earlier putting-out systems entailed (Finkin 2016). Indian freelancers continue in these jobs, notwithstanding the challenges and problems, due to poor labour market conditions in their own country, which do not offer them equivalent employment alternatives. They cite the financial and material returns, career progression and upward mobility associated with the platform as important considerations in the trade-off. Race and class dynamics are not limited solely to the hegemony of the Global North, but class issues of the Global South, linked to people's aspirations, must also inform our understanding of the complexities of platform work as offshored means of informal yet unregulated and non-unionised employment.

While the NIDL manifested at the level of whole industry and international trade between corporations, digital platforms engender interactions between individual requesters and freelancers. The NIPL, therefore, advances the NIDL beyond specific manufacturing industries; rather, the outsourcing affects 
a series of occupations and professions (e.g., IT, translation) spread across different sectors, mostly focused on the service and knowledge economies. Therefore, for Chinese and Indian freelancers, while online platforms offer them opportunities to work with clients from developed countries, they have to negotiate the global job market as individuals, and many experience discrimination linked to their geographical locations and ethnicities. The experiences of these Upworkers represent the individual challenge of being part of the NIPL. The workers are neither drawn from the working classes nor engage in predominantly manufacturing industries. Nonetheless, the freelancers in our study also report difficulties negotiating transnational transactions and experiences of discrimination, with little possibility of addressing power differences due to their status as isolated contractors (Caraway 2010). Freelancers from developing economies such as China and India face discrimination by requesters from the developed world who, wishing to reduce labour costs, often assume low expectation of pay from workers from China and India. Freelancers from developed countries resent the fact that Indian workers may command lower fees and therefore are competing with them and lowering the overall standard of pay. The findings can be explained by labour conditions in China and India and by requesters' assumptions about workers according to their ethnicity and geographical location, exacerbated by the existing planetary power structure (Graham \& Anwar 2019). While the NIDL originally theorises about global economic currents between industries, countries and economies, digital platforms allow us to consider individual implications, comparing the effects beyond the Western viewpoint. The discrimination that has been cited reminds us of offshoring operations and the concerns of imperialism by the Global North (Noronha \& D'Cruz 2009), which only reinforces the position that digital labour operates within the hierarchies of the New Global Division of Labour (Huws 2012; Su 2009), which exist both offline and online (D’Cruz 2017). As the neo-liberal project progresses against a backdrop of unprecedented technological innovation and expansion (D'Cruz \& Noronha 2016), and despite purported greater worldwide integration into global oneness (Castells 2010), the hegemony of the developed world persists (Posthuma \& Nathan 2010), emphasising the 'societal embeddedness' of global production networks which militate against any reduction of pre-existing inequalities (Coe et al. 2008).

Unlike the previous waves of manufacturing outsourcing, digital platforms participate in facilitating the NIPL through exporting the weightless knowledge industry and the labour conditions associated with precarious, insecure employment. It is difficult for Chinese and Indian freelancers to address these labour conditions given that the idea of the putting-out system is meant to avoid legal regulations. In the context of platforms, this is achieved by constructing an arms-length relationship with self-employed independent con- 
tractors (Finkin 2016). In pitching workers from the developing world against workers from the developed world, global platforms such as Upwork impact individual workers in matters of wages and job security. Importantly, workers from the originating economies of the Global North come into direct competition with their counterparts from the Global South. This means that workers' potential for collective action against their putative employers is substantially reduced. Further, as in the putting-out system, freelancers experience a lack of contact with other workers, a constant need for new work and a wide array of potential purchasers of their services which stymie the growth of collective action (Finkin 2016). Although subsumed under the capitalist logic of global crowdsourcing platforms, Upworkers in China and India are not the impoverished blue-collar workers that the NIDL originally theorises about. What is relevant here is the NIPL, which incorporates individual workers, including freelance professionals, and exports not only 'jobs' but also ideas associated with neo-liberal economies including entrepreneurialism and individualism. Overall, Chinese and Indian freelancers on online platforms are happy with the opportunities to realise both participation in the world economy and self-sufficiency within the increasingly valued ethos of individualism. This is an emerging trend to note, given that both India and China are considered to be collectivist societies (Hofstede 1980); the increase in engaging with platform work, therefore, speaks to changes in the national ethos arising due to global influences in thought processes as well as economic imperatives, particularly in the era after the global economic crisis of the late 2000s (D'Cruz \& Noronha 2016; Hansen \& Svarverud 2010; Schmalz \& Ebenau 2012). Clearly, cultural differences, far from being fixed and static, are in fact dynamic, fluid and situationally constructed (Noronha \& Magala 2017). Freelancers' participation in global capital is conditioned by their compliance with the mechanisms and stipulations centralised through the platform (resembling the panopticon; Ouellet 2010). Platforms such as Upwork engender the individualisation of labour, perceived as empowering workers, while absorbing freelancers into a new capitalist logic within national and international conditions.

\section{NOTES}

1. David Harvey defines neo-liberalism as 'a theory of political economic practices that proposes that human well-being can best be advanced by liberating individual entrepreneurial freedoms and skills within an institutional framework characterized by strong private property rights, free markets, and free trade' (2005, p. 2).

2. https://data.worldbank.org/indicator/NY.GDP.PCAP.CD (accessed 14 December 2019).

3. Promulgated by the ILO since 1999 as a means of worldwide labour regulation to address the emerging global business context, decent work comprises four pillars: full and productive employment, rights at work ensuring human dignity, social 
protection, and social dialogue (ILO 1999), encompassing the ILO's core labour standards and demonstrating its new commitment to workers previously excluded from these provisions (Ghai 2003; Vosko 2002). It focuses on eight core conventions (against child labour and forced labour and for free collective bargaining and non-discrimination on grounds of religion, gender, race, etc.) within a broad non-binding framework whose conditions are not fixed by the ILO but engender international consensus about fairness at work, with specific details being worked out locally (Ghai 2003; Moore et al. 2015).

4. https://data.worldbank.org/indicator/SL.UEM.TOTL.ZS (accessed 14 December 2019).

5. China National Bureau of Statistics. https://www.weforum.org/agenda/2017/04/ higher-education-in-china-has-boomed-in-the-last-decade (accessed 14 December 2019).

6. The policy was changed in 2015 , but the effects of this would not have been apparent in the sample in 2016.

\section{REFERENCES}

Aloisi, A. (2015), 'The Rising of On-demand Work: A Case Study Research on a Set of Online Platforms and Apps', The 4th ILO Conference on Regulating for Decent Work, ILO, Geneva, 8-10 July.

Beerepoot, N. \& Lambregts, B. (2015), 'Competition in Online Job Marketplaces: Towards a Global Labour Market for Outsourcing Services?', Global Networks, 15(2), 236-255.

Bergvall-Käreborn, B. \& Howcroft, D. (2014), 'Amazon Mechanical Turk and the Commodification of Labour', New Technology, Work and Employment, 29(3), 213-223.

Bieler, A. \& Lee, C. (2017a), 'Chinese Labour in the Global Economy: An Introduction', Globalizations, 14(2), 179-188.

Bieler, A. \& Lee, C. (2017b), 'Exploitation and Resistance: A Comparative Analysis of the Chinese Cheap Labour Electronics and High-Value Added IT Sectors', Globalizations, 14(2), 202-215.

Burbank, P.M. and Martins, D.C. (2010), 'Symbolic Interactionism and Critical Perspective: Divergent or Synergistic?', Nursing Philosophy, 11(1), 25-41.

Caraway, B. (2010), 'Online Labour Markets: An Inquiry into oDesk Providers', Organisation, Labour and Globalisation, 4(2), 111-125.

Castells, M. (2010), The Power of Identity: The Information Age: Economy, Society, and Culture. Chichester: Blackwell.

Chen, J.Y. (2018), 'Thrown Under the Bus and Outrunning It! The Logic of Didi and Taxi Drivers' Labour and Activism in the On-demand Economy', New Media \& Society, 20(8), 2691-2711.

Coe, N.M., Dicken, P. \& Hess, M. (2008), 'Global Production Networks: Realizing the Potential', Journal of Economic Geography, 8(3), 271-295.

Cohen, N. (2015), 'Entrepreneurial Journalism and the Precarious State of Media Work', South Atlantic Quarterly, 114(3), 513-533.

Cooke, F.L. (2016), 'Employment Relations in China'. In G.J. Bamber, R.D. Lansbury, N. Wailes \& C.F. Wright (eds), International and Comparative Employment Relations: National Regulation, Global Changes. Sage Publications Ltd, pp. 291-315. 
Cushing, E. (2013), Amazon Mechanical Turk: The Digital Sweatshop. UTNE Reader. https://www.utne.com/science-and-technology/amazon-mechanical-turk -zm0z13jfzlin (accessed 10 September 2018).

D'Cruz, P. (2017), 'Partially Empowering but Not Decent? The Contradictions of Online Labour Markets'. In E. Noronha \& P. D’Cruz (eds), Critical Perspectives on Work and Employment in Contemporary India. New Delhi: Springer, pp. 173-198.

D'Cruz, P. \& Noronha, E. (2012), 'High Commitment Management Practices Re-examined: The Case of Indian Call Centres', Economic and Industrial Democracy, 33(2), 185-205.

D'Cruz, P. \& Noronha, E. (2016), 'Positives Outweighing Negatives: The Experiences of Indian Crowdsourced Workers', Work Organization, Labour and Globalization, 10(1), 44-63.

D'Cruz, P. \& Noronha, E. (2018a), 'Target Experiences of Workplace Bullying on Online Labour Markets: Uncovering the Nuances of Resilience', Employee Relations, 40(1), 139-154.

D'Cruz, P. \& Noronha, E. (2018b), 'Abuse on Online Labour Markets: Targets' Coping, Power and Control', Qualitative Research in Organizations and Management, 13(1), 53-78.

D’Cruz, P. \& Noronha, E. (2019), 'Indian Freelancers in the Platform Economy: Prospects and Problems'. In K.R. Shyamsundar (ed.), Globalization, Labour Market Institutions, Policies and Processes in India. New Delhi: Palgrave, pp. 257-276.

De Stefano, V.M. (2016a), The Rise of the 'Just-in-Time' Workforce. Geneva: ILO. https://www.ilo.org/wcmsp5/groups/public/---ed_protect/---protrav/---travail/ documents/publication/wcms_443267.pdf (accessed 13 December 2019).

De Stefano, V.M. (2016b), 'Introduction: Crowdsourcing, the Gig-economy and the Law', Comparative Labor Law \& Policy Journal, 37(3), 1-10.

Djurkovic, N. (2018), 'Workplace Bullying in Precarious Employment'. In P. D'Cruz et al. (eds), Handbooks of Workplace Bullying, Emotional Abuse and Harassment: Special Topics and Particular Occupations, Professions and Sectors. Singapore: Springer, pp. 1-28.

Elena, S. (2017), The Secrets of the World's Second Largest Freelance Economy India. YKA. https:/www.youthkiawaaz.com/2017/10/the-rise-of-indias-freelance -economy/ (accessed 10 September 2018).

Ettlinger, N. (2016), 'The Governance of Crowdsourcing: Rationalities of the New Exploitation', Environment and Planning A: Economy and Space, 48(11), 2162-2180.

Finkin, M. (2016), 'Beclouded Work in Historical Perspective', Comparative Labor Law \& Policy Journal, 37(3), 16-12.

Frobel, V., Heinrichs, J. \& Kreye, O. (1978), 'The New International Division of Labour', Social Science Information, 17(1), 123-142.

Fuchs, C. (2013), 'Class and Exploitation on the Internet'. In T. Scholz (ed.), Digital Labor. The Internet as Playground and Factory. Abingdon: Routledge, pp. 211-224.

Fuchs, C. (2016), 'Digital Labor and Imperialism', Monthly Review, 67(8), 14.

Ghai, D. (2003), 'Decent Work: Concept and Indicators', International Labour Review, 142(2), 113-145.

Graham, M. \& Anwar, M.A. (2019), 'The Global Gig Economy: Towards a Planetary Labour Market?', First Monday, 24(4) n.p. https://firstmonday.org/ojs/index.php/ $\mathrm{fm} / \mathrm{rt} /$ printerFriendly/9913/7748 
Graham, M., Hjorth, I. \& Lehdonvirta, V. (2017), 'Digital Labour and Development: Impacts of Global Digital Labour Platforms and the Gig Economy on Worker Livelihoods', Transfer: European Review of Labour and Research, 23(2), 135-162.

Green, A., De Hoyos, M., Barnes, S., Baldauf, B., Behle, H. \& Stewart, J. (2013), Exploratory Research on Internet-enabled Work Exchanges and Employability. Seville, Spain: Publications Office of the European Union.

Hansen, M.H. \& Svarverud, R. (2010), iChina: The Rise of the Individual in Modern Chinese Society. Copenhagen: NIAS Press.

Hart-Landsberg, M. (2015), 'From the Claw to the Lion: A Critical Look at Capitalist Globalization', Critical Asian Studies, 47(1), 1-23.

Harvey, D. (2005), A Brief History of Neoliberalism. Oxford \& New York: Oxford University Press.

Hofstede, G. (1980), Culture's Consequences: International Differences in Work-related Values. Beverly Hills, CA: Sage.

Holtgrewe, U. (2014), 'New New Technologies: The Future and the Present of Work in Information and Communication Technology', New Technology, Work and Employment, 29(1), 9-24.

Howe, J. (2006), 'The Rise of Crowdsourcing', Wired. https://www.wired.com/2006/ 06/crowds/ (accessed 10 September 2018).

Huws, U. (2012), 'The Reproduction of Difference: Gender and the Global Division of Labour', Work Organisation, Labour \& Globalisation, 6(1), 1-10.

Huws, U. (2013), 'Working Online, Living Offline: Labour in the Internet Age', Work Organization, Labour and Globalization, 7(1), 1-11.

ILER (2014), Workers in the Era of Globalization. New Delhi: IHD and Academic Foundation.

ILO (1999), Decent work: Report of the Director-General to the International Labour Conference. http://www.ilo.org/public/english/standards/relm/ilc/ilc87/rep-i .htm(accessed 20 February 2015).

ILO (2018), Women and Men in the Informal Economy: A Statistical Picture. Third edition. Geneva: ILO.

Irani, L.C. (2015). 'Difference and Dependence among Digital Workers: The Case of Amazon Mechanical Turk', South Atlantic Quarterly, 114(1), 225-234.

Kalleberg, A.L. (2012), 'Job Quality and Precarious Work: Clarifications, Controversies, and Challenges', Work and Occupations, 39(4), 427-448.

Kantor, P., Rani, U. \& Unni, J. (2006), 'Decent Work Deficits in Informal Economy: Case of Surat', Economic and Political Weekly, 41(21), 2089-2097.

Kapoor, R. (2014), 'Creating "Good Jobs"', Economic and Political Weekly, 59(46), $16-18$.

Keat, R. (1991), 'Introduction: Starship Britain or Universal Enterprise'. In R. Keat \& N. Abercrombie (eds), Enterprise Culture. London: Routledge, pp. 1-17.

Kenney, M. \& Zysman, J. (2016), 'The Rise of the Platform Economy', Issues in Science and Technology, 32(3), 61-69.

Kittur, A., Nickerson, J.V., Bernstein, M.S., Gerber, E.M., Shaw, A., Zimmerman, J., Lease, M. \& Horton, J.J. (2013), 'The Future of Crowd Work', Conference on Computer Supported Cooperative Work, San Antonio, Texas, 13 February.

Kneese, T., Rosenblat, A. \& Boyd, D. (2014), 'Understanding Fair Labor Practices in a Networked Age', Open Society Foundations. https://www.datasociety.net/pubs/ fow/FairLabor.pdf (accessed 10 September 2018).

Lal, S. (2015), 'Thanks to Internet, India has Most Freelance Professionals after US', Hindustan Times. https://www.hindustantimes.com/tech/tech-internet-combine-to 
-create-unconventional-career-options/story-1kHKXGcYpUiEMgyTYT9nNO.html (accessed 10 September 2018).

Leung, W.F. (2018), Digital Entrepreneurship, Gender and Intersectionality: An East Asian Perspective. London: Palgrave Macmillan.

Leung, W.F. \& Cossu, A. (2019), 'Digital Entrepreneurship in Taiwan and Thailand: Embracing Precarity as a Personal Response to Political and Economic Change', International Journal of Cultural Studies, 22(2), 264-280.

Liang, Z., Appleton, S. \& Song, L. (2016), Informal Employment in China: Trends, Patterns and Determinants of Entry. Bonn: Institute for the Study of Labor (IZA).

Milkman, R. \& Ott, E. (2014), New Labor in New York. Ithaca, NY: Cornell University Press.

Moore, P. (2018), The Threat of Physical and Psychosocial Violence and Harassment in Digitalized Work. Geneva: ILO.

Moore, P., Dannreuther, C. \& Möllmann, C. (2015), 'Guest Editors' Introduction: The Future and Praxis of Decent Work', Global Labour Journal, 6(2), 127-137.

Nash, J. (1983), 'Introduction'. In J. Nash \& M.P. Fernandez-Kelly (eds), Women, Men and the International Division of Labour. Albany: State University of New York.

Noronha, E. (1996), 'Liberalisation and Industrial Relations', Economic and Political Weekly, 31(8), L14-L20.

Noronha, E. \& Beale, D. (2011), 'India, Neo-liberalism and Union Responses: Unfinished Business and Protracted Struggles'. In G. Gregor, A. Wilkinson \& R. Hurd (eds), The International Handbook of Labour Unions: Responses to Neo-liberalism. Cheltenham, UK and Northampton, MA, USA: Edward Elgar, pp. 167-186.

Noronha, E. \& D'Cruz, P. (2008), 'The Dynamics of Teleworking: Case Studies of Women Medical Transcriptionists from Bangalore, India', Gender, Technology and Development, 12(2), 157-183.

Noronha, E. \& D'Cruz, P. (2009), Employee Identity in Indian Call Centres: The Notion of Professionalism. New Delhi: Sage.

Noronha, E. \& D'Cruz, P. (2016), 'Still a Distance to Go: Social Upgrading in the Indian ITO-BPO-KPO Sector'. In D. Nathan, M. Tewari \& S. Sarkar (eds), Labour in Global Value Chains in Asia. Cambridge: Cambridge University Press, pp. 423-449.

Noronha, E. \& D'Cruz, P. (2018), 'Indian Freelancers' Experiences of Bullying on Online Labour Markets: Insights into Digital Workplaces in the Informal Economy'. In P. D'Cruz et al. (eds), Indian Perspectives on Workplace Bullying: A Decade of Insights. Singapore: Springer, pp. 147-172.

Noronha, E. \& D'Cruz, P. (2019), 'Organization Advantage: Experience of Telework in India'. In J. C. Messenger (ed.), Telework in the 21st Century. Cheltenham, UK and Northampton, MA, USA: Edward Elgar Publishing, pp. 255-285.

Noronha, E. \& Magala, S. (2017), 'Going Dutch, Remaining Indian: The Work Experiences of IT Expatriates'. In E. Noronha \& P. D'Cruz (eds), Critical Perspectives on Work and Employment in Globalizing India. Singapore: Springer, pp. 283-303.

Noronha, E., D’Cruz, P. \& Banday, M.U.L. (2018), 'Navigating Embeddedness: Experiences of Indian IT Suppliers and Employees in the Netherlands', Journal of Business Ethics. DOI: 10.1007/s10551-018-4071-3.

Ong, A. (2006), Neoliberalism as Exception: Mutations in Citizenship and Sovereignty. Durham, NC: Duke University Press. 
Ouellet, M. (2010), 'Cybernetic Capitalism and the Global Information Society: From the Global Panopticon to a "Brand" New World'. In M. Paterson \& J. Best (eds), Cultural Political Economy. London: Routledge, pp. 177-196.

Pongratz, H.J. (2018), 'Of Crowds and Talents: Discursive Constructions of Global Online Labour', New Technology, Work and Employment, 33(1), 58-73.

Pongratz, H.J. \& Voss, G.G. (2003), 'From Employee to "Entreployee": Towards a “Self-entrepreneurial” Work Force?', Concepts and Transformation, 8(3), 239-254.

Posthuma, A. \& Nathan, D. (2010), Labour in Global Production Networks in India. New Dehli: Oxford University Press.

Rustagi, P. (2015), 'Informal Employment Statistics: Some Issues', Economic and Political Weekly, 50(6), 67-72.

Schmalz, S. \& Ebenau, M. (2012), 'After Neoliberalism? Brazil, India, and China in the Global Economic Crisis', Globalizations, 9(4), 487-501.

Schucher, G. (2017), 'The Fear of Failure: Youth Employment Problems in China', International Labour Review, 156(1), 73-98.

Sinha, J.B.P. (2015), Psychosocial Analysis of the Indian Mindset. New Delhi: Springer.

Standing, G. (1999), Global Labour Flexibility. New York: St. Martin's Press.

Standing, G. (2011), The Precariat: The New Dangerous Class. New York: Bloomsbury.

$\mathrm{Su}, \mathrm{Z}$. (2009), 'Place of China in the New International Division of Labour', Proceedings of Global Management Conference, Río de Janeiro.

Urry, J. (2014), Offshoring. Cambridge: Polity.

Vosko, L.F. (2002), 'Decent Work: The Shifting Role of the ILO and the Struggle for Global Social Justice', Global Social Policy, 2(1), 19-46.

Vosko, L.F. (2009), Managing the Margins: Gender, Citizenship, and the International Regulation of Precarious Employment. Oxford: Oxford University Press.

Williams, C.C. (2017), 'Re-classifying Economies by the Degree and Intensity of Informalization: The Implications for India'. In E. Noronha \& P. D'Cruz (eds), Critical Perspectives on Work and Employment in Contemporary India. New Delhi: Springer, pp. 113-132.

Wood, A.J., Graham, M., Lehdonvirta, V. \& Hjorth, I. (2018), 'Good Gig, Bad Gig: Autonomy and Algorithmic Control in the Global Gig Economy', Work, Employment and Society, 33(1), 56-75. 